FIT(1)PATOLOGI
IN D ONES IA
ISSN: 0215-7950
Insidensi Penyakit Busuk Bulir Padi, Identifikasi, dan
Keragaman Bakteri Burkholderia glumae pada
Beberapa Varietas Padi di Jawa Barat

\title{
Incidence of Bacterial Grain Rot Disease, Identification, and Diversity of Burkolderia glumae in Some Rice Varieties in West Java
}

\author{
Ani Widarti, Giyanto*, Kikin Hamzah Mutaqin \\ Institut Pertanian Bogor, Bogor 16680
}

\begin{abstract}
ABSTRAK
Penyakit busuk bulir padi oleh bakteri Burkholderia glumae perlu diwaspadai termasuk di Jawa Barat sebagai salah satu sentra produksi padi nasional. Penelitian ini bertujuan untuk menentukan insidensi penyakit, identitas dan keragaman bakteri B. glumae pada beberapa varietas padi di Provinsi Jawa Barat. Pengamatan insidensi penyakit dan pengambilan sampel dilakukan di 9 kabupaten. Bakteri diisolasi dari bulir padi yang bergejala busuk bulir kemudian dilakukan uji biokimia dan fisiologi yang meliputi uji Gram serta uji pertumbuhan pada $\mathrm{pH} 4.8$, dan $\mathrm{NaCl} 2 \%$. Variasi fenotipik diamati dari warna koloni pada medium S-PG, produksi toksofalvin, respons hipersensitivitas pada daun tembakau, dan uji patogenisitas pada tanaman padi. Primer spesifik JLBgF/JLBgR dan primer universal 16S rRNA, yaitu 27F/1492R digunakan untuk menentukan identitas bakteri secara molekuler. Insidensi penyakit di lapangan berkisar antara 0-73.3\%, tertinggi di Kecamatan Dawuan (Karawang) pada var. Mekongga. Berdasarkan uji biokimia dan fisiologi diperoleh 29 isolat terkonfirmasi sebagai B. glumae. Hasil pengamatan fenotipik menunjukkan 10 isolat tergolong koloni tipe A, 19 isolat tipe B; 25 isolat menghasilkan toksoflavin; 29 isolat menimbulkan respons hipersensitivitas pada daun tembakau dan gejala hawar pada tanaman padi. Identifikasi menggunakan primer spesifik dan universal membuktikan 29 isolat adalah B. glumae. Analisis keragaman genotip menunjukkan bahwa isolat KRCH-2 (Karawang) dan INCH-6 (Indramayu) memiliki hubungan kekerabatan yang dekat dengan B. glumae asal Cina dan Amerika.
\end{abstract}

Kata kunci: bulir padi, keragaman fenotip, keragaman genotip, respons hipersensitivitas, uji patogenisitas

\begin{abstract}
Rice rot disease caused by the bacteria Burkholderia glumae needs to be looked out, including in West Java as one of rice production center for Indonesia. This study was carried out to determine disease incidence, identity and diversity of B. glumae in several rice varieties grown in West Java Province. Sampling and observation of disease incidence were conducted in 9 districts. Bacteria were isolated from rice grains with symptomatic rot, followed by biochemical and physiological tests involving Gram and growing tests at $\mathrm{pH} 4.8$ and $2 \% \mathrm{NaCl}$. Phenotypic variation was observed from the colony color on S-PG media, toxofalvin production, hypersensitivity response to tobacco leaves, and pathogenicity test on rice plants. B. glumae specific primers, $\mathrm{JLBgF} / \mathrm{JLBgR}$, and bacteria universal $16 \mathrm{~S}$ rRNA primers, 27F/1492R were used to determine molecular identity. Genotypic diversity analysis was performed using
\end{abstract}

*Alamat penulis korespondensi: Departemen Proteksi Tanaman, Fakultas Pertanian, Institut Pertanian Bogor. Jalan Kamper Kampus IPB Darmaga, Bogor 16680.

Tel: 0251-8629364, Faks: 0251-862362, surel: giyanto2@yahoo.com. 
neighbour-joining tree method. Disease incidence was in the range of $0-73.3 \%$, the highest was found in Dawuan District (Karawang) on var. Mekongga. The phenotypic observations showed 10 isolates belonging to type A colonies and 19 isolates of type B; 25 isolates produced toxoflavin; 29 isolates produced hypersensitivity responses to tobacco leaves and blight symptoms in rice plants. Identification using specific and universal primers confirmed that 29 isolates were $B$. glumae. The genotypic diversity analysis of $16 \mathrm{~S}$ rRNA gene showed that KRCH-2 isolates (Karawang) and INCH-6 (Indramayu) were closely related to B. glumae from China and America.

Key words: genotypic diversity, hypersensitivity response, pathogenicity test, phenotypic diversity, rice grain

\section{PENDAHULUAN}

Penyakit busuk bulir oleh bakteri Burkholderia glumae dilaporkan pertama kali di Indonesia pada tahun 1987 di Kecamatan Indihiang, Kabupaten Tasikmalaya (Direktorat Bina Perlindungan Tanaman Pangan 1992). Pada 5 tahun terakhir dilaporkan terjadi ledakan penyakit ini di Sulawesi Selatan dan Pulau Jawa (Baharuddin et al. 2017; Wiyono et al. 2017). Penyakit busuk bulir dicirikan dengan bulir padi mengalami pembusukan bahkan hampa sehingga menyebabkan kehilangan hasil yang nyata. Baharuddin et al. (2017) melaporkan bahwa intensitas serangan bakteri B. glumae di Kecamatan Bantimurung, Kabupaten Maros berkisar antara 25-55\% dan menyebabkan kehilangan hasil antara 20-48\%. Bakteri ini diketahui dapat terbawa benih sehingga berpotensi menyebar dengan cepat. Faktor-faktor seperti importasi benih, perubahan iklim global dan cara budi daya diduga berhubungan dengan terjadinya ledakan penyakit ini (Joko 2017).

Penyakit busuk bulir bakteri dikategorikan sebagai emerging infectious disease (EID) yang memiliki karakteristik meningkatnya insidensi, sebaran geografis, dan berubahnya patogenisitas dalam waktu singkat. EID dapat disebabkan oleh perubahan iklim, teknik budi daya, perubahan habitat, perubahan genetik, dan introduksi patogen (Wiyono et al. 2017). Suhu tinggi terutama pada malam hari dengan kelembapan relatif tinggi mendukung kemampuan infeksi bakteri dan perkembangan penyakit busuk bulir. Kisaran suhu antara $30^{\circ} \mathrm{C}$ dan $31{ }^{\circ} \mathrm{C}$ optimum bagi pertumbuhan $B$. glumae (Nandakumar et al. 2009).
Lim et al. (2009) melakukan sikuen genom lengkap isolat BGR1 dan melaporkan bahwa B. glumae BGR1 terdiri atas 2 kromosom dan 4 plasmid. Gen biosintesis dan gen lain yang terkait dengan patogenisitas ditemukan pada kromosom 2. Ada keragaman virulensi, produksi toksoflavin, pigmentasi, dan sidik jari DNA pada 24 strain bakteri B. glumae yang diisolasi dari pertanaman padi di wilayah Amerika bagian selatan (Karki et al. 2012).

Infeksi $B$. glumae dilaporkan pada padi varietas Ciherang yang berasal dari Cirebon (Handiyanti et al. 2018). Biologi dan ekologi bakteri $B$. glumae di Indonesia khususnya Jawa Barat perlu dikaji lebih lanjut guna pengambilan keputusan pengelolaan penyakit yang tepat. Penelitian dilakukan untuk menentukan insidensi penyakit, identifikasi dan keragaman bakteri $B$. glumae pada beberapa varietas padi di Propinsi Jawa Barat.

\section{BAHAN DAN METODE}

\section{Pengamatan Gejala dan Insidensi Penyakit}

Pengambilan sampel dan pengamatan tanaman padi dilakukan di Provinsi Jawa Barat pada lokasi dengan ketinggian tempat yang bervariasi, yaitu kategori 1 (0-200 m dpl), kategori 2 (201-500 m dpl) dan ketegori $3(>500 \mathrm{~m} \mathrm{dpl})$ (Tabel 1). Pengamatan insidensi penyakit mengacu pada petunjuk teknis pengamatan dan pelaporan organisme pengganggu tumbuhan dan dampak perubahan iklim (Direktorat Perlindungan Tanaman Pangan 2018). Pengamatan dilakukan pada 30 rumpun per petak untuk varietas yang sama ditandai dengan pola zig zag. Insidensi penyakit (IP) dihitung menggunakan rumus: 


$$
\mathrm{IP}(\%)=\frac{\mathrm{n}}{\mathrm{N}} \times 100 \% \text {, dengan }
$$

$\mathrm{n}$, jumlah tanaman yang sakit, dan $\mathrm{N}$, jumlah seluruh tanaman yang diamati.

\section{Isolasi B. glumae}

Sebanyak $1 \mathrm{~g}$ sampel bulir padi bergejala busuk bulir digerus dalam mortar dan disuspensikan dalam $10 \mathrm{~mL}$ air steril. Suspensi diencerkan bertingkat hingga $10^{-7}$. Sebanyak $0.1 \mathrm{~mL}$ dari masing-masing pengenceran disebar pada medium sucrosephosphate glutamate (S-PG: 1.3 g KH2PO4; $1.2 \mathrm{~g} \mathrm{Na} \mathrm{NPO}_{4}, 5 \mathrm{~g}(\mathrm{NH} 4)_{2} \mathrm{SO}_{4} ; 0.25 \mathrm{~g}$ $\mathrm{MgSO}_{4} \cdot 7 \mathrm{H}_{2} \mathrm{O}, 24 \mathrm{mg} \mathrm{Na} \mathrm{MoO}_{4} \cdot 2 \mathrm{H}_{2} \mathrm{O} ; 10 \mathrm{mg}$ EDTA-Fe; $10 \mu \mathrm{g}$ L-cystine; $15 \mathrm{~g}$ agar; $10 \mathrm{~g}$ D-sorbitol; $50 \mathrm{mg}$ pheneticilin potassium; $10 \mathrm{mg}$ ampicilin sodium; $10 \mathrm{mg}$ cetrimide; $1 \mathrm{mg}$ methyl violet dan $20 \mathrm{mg}$ phenol red per liter medium). Inkubasi dilakukan selama 5-7 hari. Bakteri yang tumbuh dikelompokkan berdasarkan morfologi dan dimurnikan pada medium S-PG (Chun dan Jones 2001).

\section{Sifat biokimia dan fisiologi $B$. glumae}

Pengujian sifat biokimia dan fisiologi meliputi uji Gram, pertumbuhan bakteri pada pH 4 dan 8 serta pertumbuhan pada medium yang mengandung $\mathrm{NaCl} \quad 2 \%$ mengikuti metode Chun dan Jones (2001). Tipe Gram bakteri ditentukan dengan pewarnaan Gram dan pengujian $\mathrm{KOH} 3 \%$. Kemampuan tumbuh bakteri pada suasana asam, basa, dan salin dilakukan dengan menumbuhkan bakteri pada medium luria bertani broth (LB) dengan $\mathrm{pH} 4$ dan 8 serta nutrient broth yeast extract (NBY) yang mengandung $\mathrm{NaCl} 2 \%$. Pengamatan pertumbuhan bakteri dilakukan mulai dari 24 jam setelah inokulasi dengan mengukur pertumbuhan bakteri menggunakan spektrofotometer.

\section{Keragaman Fenotip B. glumae}

Keragaman fenotip bakteri $B$. glumae didasarkan pada warna koloni di medium S-PG, produksi toksoflavin, uji respons hipersensitivitas, dan uji patogenisitas. Uji produksi toksoflavin merujuk pada Karki et al. (2012). Biakan bakteri digoreskan pada medium King's B (KB) yang mengandung $80 \%$ gliserol kemudian diinkubasi pada suhu $37{ }^{\circ} \mathrm{C}$ selama $24-72$ jam. Warna kuning yang terdifusi pada medium sebagai tanda diproduksinya toksoflavin.

Uji hipersensitivitas dilakukan dengan infiltrasi suspensi B. glumae dalam medium

Tabel 1 Lokasi pengamatan dan pengambilan sampel tanaman padi

\begin{tabular}{|c|c|c|c|c|}
\hline \multirow{2}{*}{ Kategori } & \multicolumn{2}{|c|}{ Lokasi } & \multirow{2}{*}{$\begin{array}{l}\text { Ketinggian tempat } \\
\text { (m dpl) }\end{array}$} & \multirow{2}{*}{ Varietas } \\
\hline & Kabupaten & Kecamatan & & \\
\hline \multirow[t]{10}{*}{1} & Karawang & Batujaya & 15 & Ciherang \\
\hline & & Kotabaru & 32 & Ciherang \\
\hline & & Dawuan & 44 & Mekongga \\
\hline & & Ciampel & 45 & Inpari 32 \\
\hline & Subang & Sukasari & 17 & Inpari 42 \\
\hline & & Binong & 28 & Inpari 30 \\
\hline & & Pabuaran & 53 & Ciherang \\
\hline & Indramayu & Bangodua & 16 & Ciherang \\
\hline & & Kandanghaur & 28 & Ciherang \\
\hline & Majalengka & Jatitujuh & 121 & IR 64 \\
\hline \multirow[t]{4}{*}{2} & Kota Bogor & Bogor Barat & 250 & IR 64 \\
\hline & Purwakarta & Pondoksalam & 296 & Ciherang \\
\hline & & Pondoksalam & 296 & Situ Bagendit \\
\hline & Cianjur & Bojongpicung & 300 & Ciherang \\
\hline \multirow[t]{3}{*}{3} & Sumedang & Sumedang Utara & 506 & Ciherang \\
\hline & Purwakarta & Wanayasa & 615 & Ciherang \\
\hline & Sukabumi & Sukaraja & 924 & Sintanur \\
\hline
\end{tabular}


King's B cair (umur 24 jam) pada tembakau menggunakan syringe (Karki 2010). Respons hipersensitif ditandai dengan munculnya gejala berupa nekrosis atau klorosis pada daun tembakau 24-48 jam setelah inokulasi.

Uji patogenisitas dilakukan dengan inokulasi bakteri pada tanaman padi varietas Ciherang yang berumur 1-1.5 bulan. Isolat bakteri ditumbuhkan pada medium King's B cair (umur 24 jam), kemudian diinokulasikan pada batang tanaman padi menggunakan syringe 1 cc 26 G. Pengamatan dilakukan berdasarkan pada sistem skoring Nandakumar (2009) (Tabel 2).

\section{Identifikasi Molekuler dan Keragaman Genotip B. glumae}

Amplifikasi DNA. Ekstraksi DNA total bakteri pada tanaman dilakukan dengan Qiamp DNA mini kit (Qiagen). Amplifikasi DNA dengan polymerase chain reaction (PCR) mengikuti protokol Top Taq master mix kit (Qiagen), menggunakan pasangan primer spesifik $B$. glumae forward 5'TGG GTA GTC TCT GTA GGG AA-3' dan reverse 5'-TCA TCC TCT GAC TGG CTC AA-3' dan pasangan primer universal 16S rRNA forward 27F 5'-AGA GTT TGA TCC TGG CTC AG3' dan reverse 1492R 5'-TAC GGY TAC CTT GTT ACG ACT T-3' dengan panjang produk target berturut-turut $164 \mathrm{pb}$ dan 1500 pb (Pradhaph et al. 2011; Lu et al. 2014). Program amplifikasi kedua target terdiri atas denaturasi awal $\left(94{ }^{\circ} \mathrm{C}, 3\right.$ menit); diikuti 35 siklus pemanasan denaturasi $\left(94{ }^{\circ} \mathrm{C}\right.$, 30 detik), aneling $\left(60{ }^{\circ} \mathrm{C}, 30\right.$ detik), dan ekstensi $\left(72{ }^{\circ} \mathrm{C}, 30\right.$ detik). Ekstensi akhir dilakukan pada suhu $72{ }^{\circ} \mathrm{C}$ selama 10 menit.

Amplikon DNA dielektroforesis dalam gel agarosa $2 \%$ pada tegangan $50 \mathrm{~V}$ DC selama 50 menit. Pita DNA dalam gel yang mengandung etidium bromida divisualisasi pada transiluminator UV.

\section{Perunutan Basa DNA dan Analisis \\ Nukleotida}

Perunutan nukleotida hasil amplifikasi gen 16S rRNA dilakukan oleh Macrogen Korea Selatan. Sikuen gen 16S rRNA dibandingkan dengan sikuen DNA bakteri yang tersedia di GenBank (B. glumae asal Cina, Amerika Selatan, Thailand, B. gladioli, dan Xanthomonas oryzae sebagai out group) dengan program basic local alignment search tool (BLAST) pada situs national center for biotechnology information (NCBI) (http:// www.ncbi.nlm.nih.gov/blast/Blast.cgi). Analisis sikuen nukleotida gen 16S rRNA dilakukan dengan metode neighbour joining tree menggunakan program Mega-X.

\section{HASIL}

\section{Gejala dan Insidensi Penyakit di Lapangan}

Gejala penyakit ditandai dengan malai membentang ke atas karena biji tidak terisi penuh, ranting malai tegak berwarna hijau dengan tulang cabang berwarna hijau (Gambar 1) dan gradasi warna pada bulir (Gambar 2). Insidensi penyakit tertinggi terjadi di Kecamatan Dawuan, Karawang (44 m dpl) yang mencapai $73.3 \%$ pada var. Mekongga. Gejala penyakit tidak ditemukan pada var. Inpari 42 (Sukasari; $17 \mathrm{~m} \mathrm{dpl),} \mathrm{var.}$ Situ Bagendit (Pondoksalam; 296 m dpl), var. Ciherang (Sumedang Utara; $506 \mathrm{~m} \mathrm{dpl}$ dan Wanayasa; $615 \mathrm{~m} \mathrm{dpl}$ ) dan var. Sintanur (Sukaraja; 915 m dpl) (Gambar 3).

Tabel 2 Sistem skoring gejala hasil perlakuan B. glumae pada bibit tanaman padi

\begin{tabular}{cl}
\hline Skor & \multicolumn{1}{c}{ Parameter } \\
\hline 0 & Tidak ada gejala \\
1 & $\begin{array}{l}\text { Terdapat lesio berwarna kecokelatan pada area inokulasi } \\
\text { Lesio keabu-abuan berdiameter } 1-2 \mathrm{~cm} \text { menyebar naik dan turun dari area suntikan } \\
\text { dengan batas tepi cokelat gelap }\end{array}$ \\
3 & $\begin{array}{l}\text { Lesio menyebar di batang dari area inokulasi, daun bagian dalam menguning atau hawar } \\
\text { dan menjadi nekrosis }\end{array}$ \\
\hline
\end{tabular}




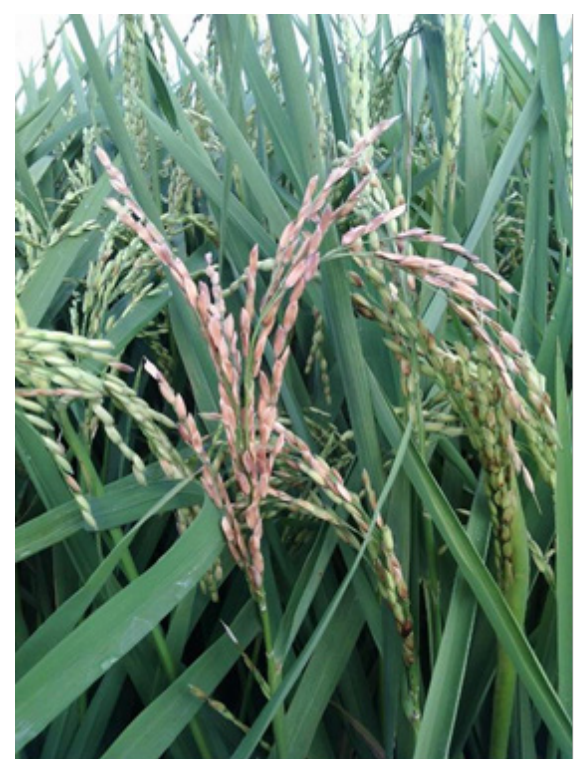

$\mathrm{a}$

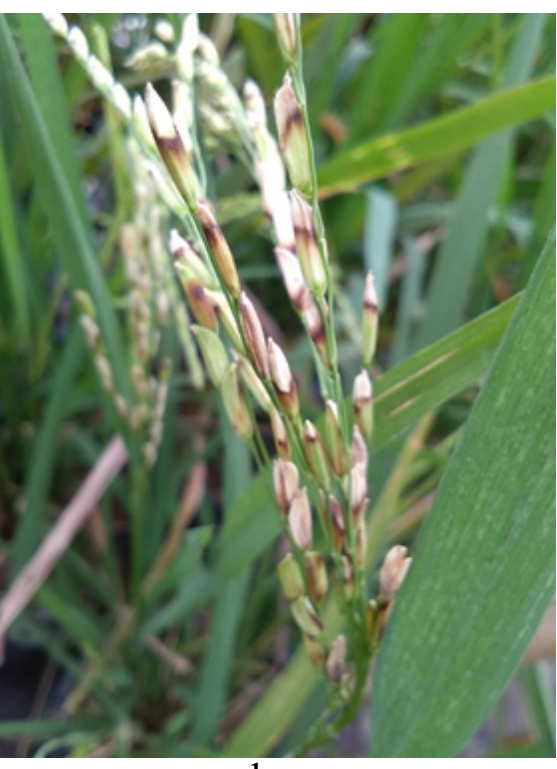

b

Gambar 1 Gejala penyakit busuk bulir pada padi var. Ciherang. a, Kecamatan Kandanghaur; dan b, Kecamatan Kotabaru.

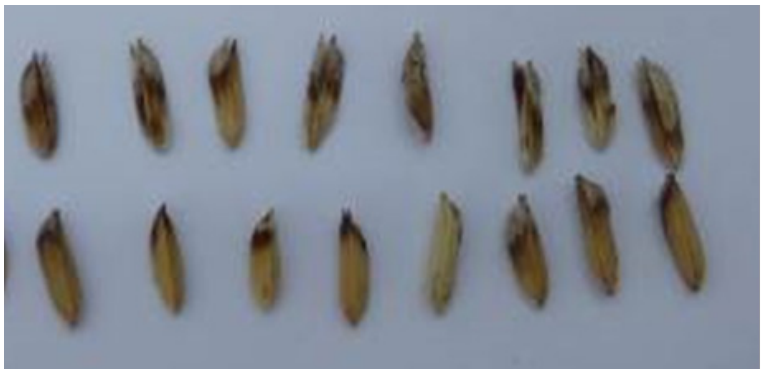

a

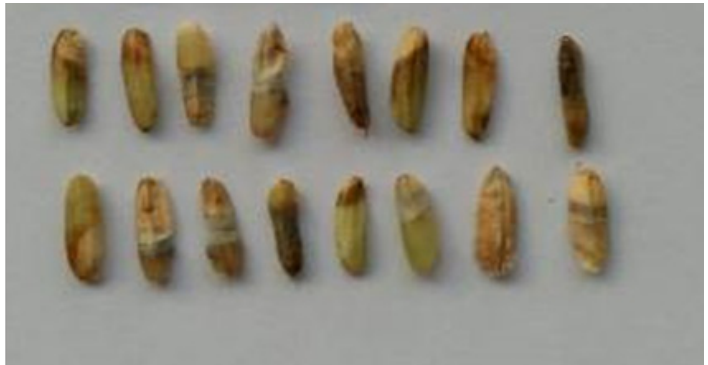

b

Gambar 2 Gejala penyakit busuk bakteri pada bulir padi. a, Gradasi warna pada bulir; dan b, Pelunakan pada beras.

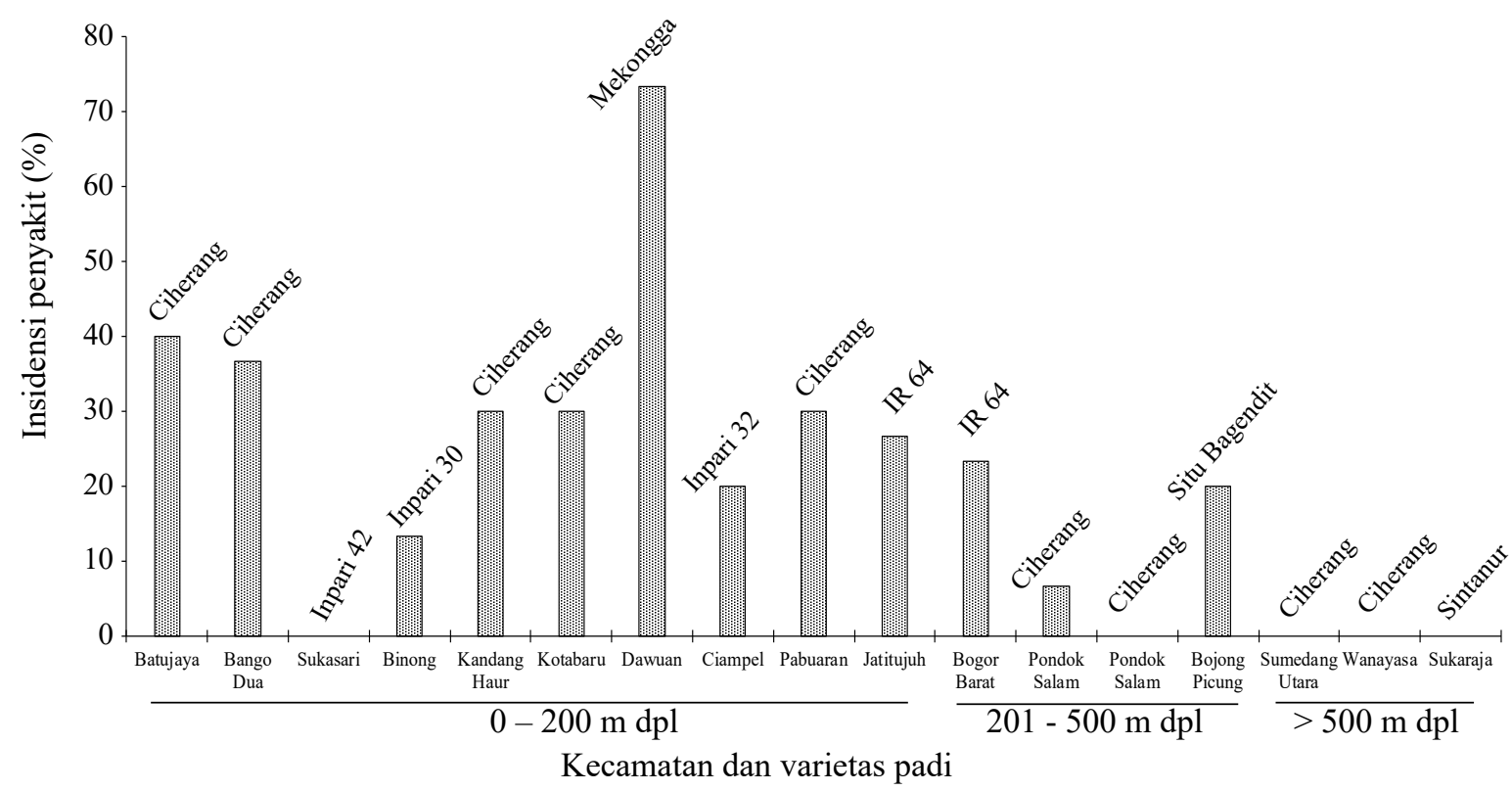

Gambar 3 nsidensi penyakit busuk bulir padi pada berbagai varietas di beberapa daerah di Jawa Barat dengan ketinggian tempat yang bervariasi. 


\section{Karakter isolat $B$. glumae}

Total isolat $B$. glumae yang diperoleh berjumlah 56 isolat. Dari hasil uji biokimia dan fisiologi, isolat yang terkonfirmasi sebagai B. glumae berjumlah 29 isolat. Seluruh isolat B. glumae merupakan bakteri Gram negatif dengan skor patogenisitas yang beragam, yaitu 1 sampai 3. Bakteri yang berhasil diisolasi tidak tumbuh pada medium dengan $\mathrm{pH} 4$. Terdapat 1 isolat (SUCH-4) tidak berhasil ditumbuhkan pada medium dengan $\mathrm{pH} 8$, tetapi 18 isolat dapat tumbuh pada medium yang mengandung $\mathrm{NaCl} 20 \%$ setelah 24 jam inokulasi (Tabel 3).

\section{Keragaman fenotip}

Koloni $B$. glumae berwarna ungu kehitaman atau kecokelatan pada medium S-PG, berbentukbulatdengan elevasicembung. Perbedaan warna koloni pada medium S-PG menjadi dasar pembagian tipe koloni, yaitu koloni tipe A (warna cokelat kemerahan) dan tipe B (warna ungu kehitaman) (Gambar 4). B. glumae isolat KRI32-1, SUCH1, MJIR2, MJIR4, dan PUCH1 tidak menghasilkan toksoflavin karena tidak menghasilkan pigmen berwarna kuning (Gambar 5). Seluruh isolat dapat menimbulkan gejala hipersensitivitas pada daun tembakau dan bersifat patogen pada tanaman dengan skor patogenisitas beragam,

Tabel 3 Karakter 29 isolat B. glumae hasil isolasi dari bulir padi

\begin{tabular}{|c|c|c|c|c|c|c|}
\hline \multicolumn{2}{|c|}{ Lokasi asal isolasi } & \multirow{2}{*}{$\begin{array}{l}\text { Kode } \\
\text { Isolat }\end{array}$} & \multirow{2}{*}{$\begin{array}{l}\text { Waktu pertumbuhan } \\
\text { pada } \mathrm{NaCl} 2 \%\end{array}$} & \multirow{2}{*}{$\begin{array}{l}\text { Tipe } \\
\text { koloni* }\end{array}$} & \multirow{2}{*}{$\begin{array}{l}\text { Produksi } \\
\text { Toksoflavin }\end{array}$} & \multirow{2}{*}{$\begin{array}{c}\text { Skor } \\
\text { Patogenisitas }\end{array}$} \\
\hline Kabupaten & Kecamatan & & & & & \\
\hline \multirow[t]{12}{*}{ Karawang } & \multirow[t]{4}{*}{ Batujaya } & KRCH-1 & 48 & B & + & 2 \\
\hline & & $\mathrm{KRCH}-2$ & 48 & A & + & 2 \\
\hline & & $\mathrm{KRCH}-3$ & 24 & A & + & 3 \\
\hline & & $\mathrm{KRCH}-4$ & 24 & B & + & 2 \\
\hline & \multirow[t]{4}{*}{ Kotabaru } & KRCH-5 & 24 & A & + & 2 \\
\hline & & KRCH-6 & 24 & A & + & 2 \\
\hline & & KRCH-7 & 24 & B & + & 3 \\
\hline & & KRCH-8 & 24 & B & + & 2 \\
\hline & \multirow[t]{2}{*}{ Dawuan } & KRMK-1 & 48 & B & + & 3 \\
\hline & & KRMK-3 & 48 & A & + & 2 \\
\hline & \multirow[t]{2}{*}{ Ciampel } & KRI32-1 & 24 & B & - & 1 \\
\hline & & KRI32-2 & 24 & B & + & 2 \\
\hline \multirow[t]{5}{*}{ Subang } & \multirow{2}{*}{ Pabuaran } & SUCH-1 & 24 & B & + & 1 \\
\hline & & SUCH-4 & 24 & B & + & 3 \\
\hline & \multirow[t]{3}{*}{ Binong } & SUI30-1 & 48 & A & + & 3 \\
\hline & & SUI30-2 & 24 & B & + & 2 \\
\hline & & SUI30-5 & 24 & B & + & 2 \\
\hline \multirow[t]{4}{*}{ Indramayu } & \multirow[t]{2}{*}{ Bangodua } & INCH-1 & 48 & B & + & 3 \\
\hline & & INCH-2 & 72 & B & + & 3 \\
\hline & \multirow[t]{2}{*}{ Kandanghaur } & INCH-4 & 24 & B & + & 3 \\
\hline & & INCH-6 & 48 & B & + & 1 \\
\hline \multirow[t]{4}{*}{ Majalengka } & \multirow[t]{4}{*}{ Jatitujuh } & MJIR-2 & 72 & B & - & 1 \\
\hline & & MJIR-3 & 72 & B & + & 3 \\
\hline & & MJIR-4 & 24 & B & - & 1 \\
\hline & & MJIR-6 & 24 & A & + & 2 \\
\hline \multirow[t]{2}{*}{ Cianjur } & \multirow[t]{2}{*}{ Bojongpicung } & CICH-2 & 24 & A & + & 2 \\
\hline & & CICH-3 & 24 & A & + & 2 \\
\hline Kota Bogor & Bogor Barat & BOIR-1 & 24 & A & + & 3 \\
\hline Purwakarta & Pondoksalam & PUCH-1 & 48 & B & - & 1 \\
\hline
\end{tabular}

*A, koloni bulat berwarna cokelat; B, koloni bulat berwarna ungu kehitaman 
mulai skor 1 sampai dengan 3 (Tabel 3; Lebih lanjut perunutan nukleotida hasil Gambar 6). amplifikasi gen 16S rRNA menunjukkan bahwa 29 isolat teridentifikasi sebagai $B$.

\section{Identifikasi dan Keragaman Genotip}

Pita DNA target berukuran $164 \mathrm{pb}$ glumae (Tabel 4). Analisis dengan metode berhasil diamplifikasi sehingga hasil tersebut mengonfirmasi identitas B. glumae (Gambar 7).

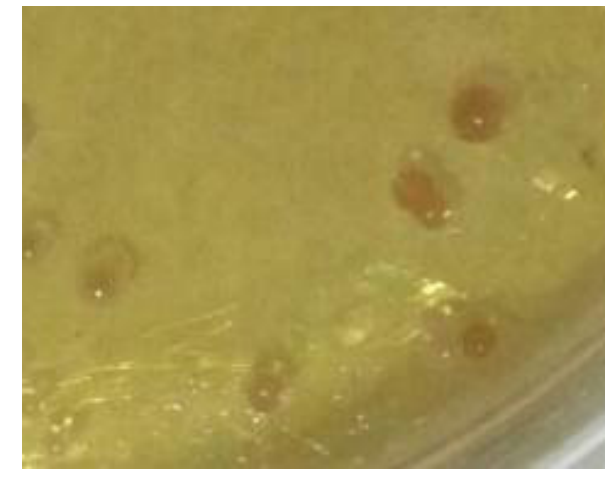

a

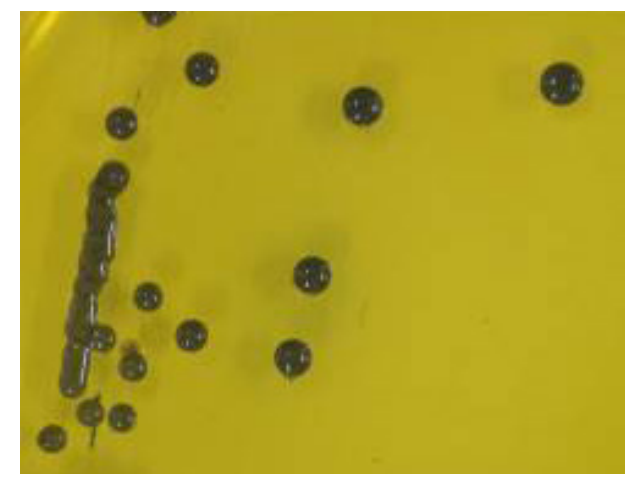

b

Gambar 4 Koloni bakteri B.glumae pada medium S-PG . a, Koloni tipe A berwarna cokelat; dan b, Koloni tipe B dengan berwarna ungu kehitaman (B).
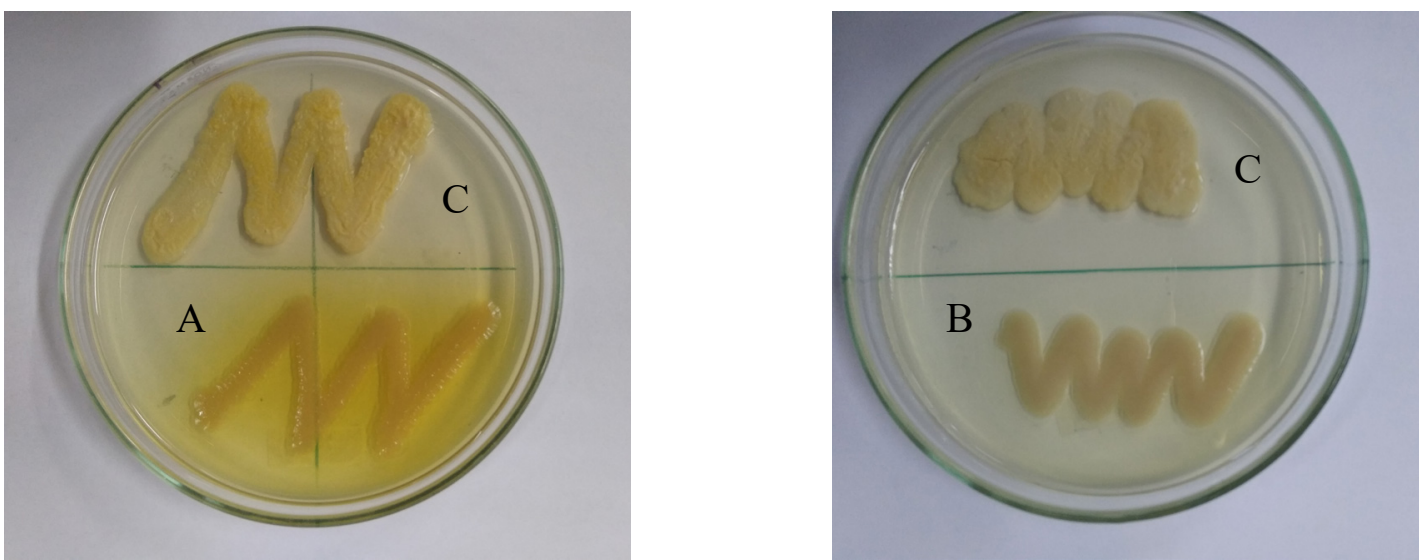

Gambar 5 Isolat B. glumae menghasilkan pigmen kuning (A) dan tidak menghasilkan pigmen (B) dengan kontrol bakteri Bacillus cereus (C).

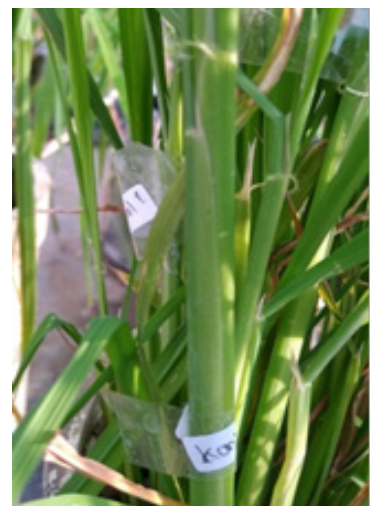

Skor 0

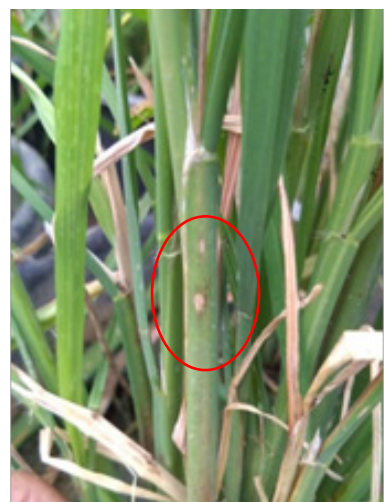

Skor 1

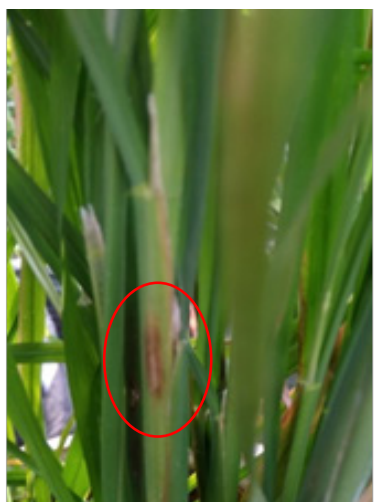

Skor 2

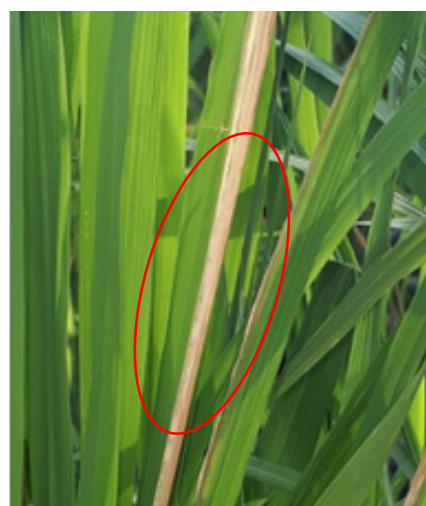

Skor 3

Gambar 6 Tingkat gejala dan skor patogenisitas isolat B. glumae pada tanaman padi. 


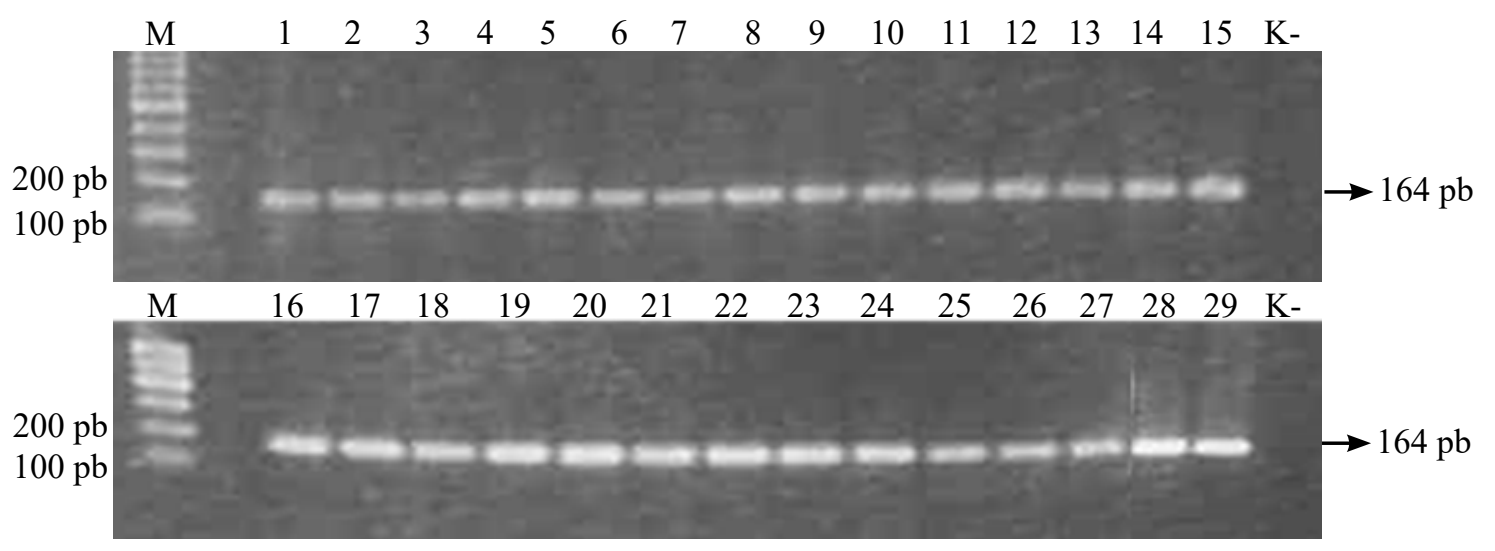

Gambar 7 Amplifikasi DNA B. glumae dari beberapa varietas padi menggunakan primer spesifik. M, Penanda DNA $1 \mathrm{~Kb}$ (Qiagen); 1, KRCH-1; 2, KRCH-2; 3, KRCH-3; 4, KRCH-4; 5, KRCH-5; 6, KRCH-6; 7, KRCH-7; 8, KRCH-8; 9, KRMK-1; 10, KRMK-3; 11, KRI321; 12, KRI32-2; 13, SUCH-1; 14, SUCH-4; 15, SUI30-1; 16, SUI30-2; 17, SUI30-5; 18, INCH-1; 19, INCH-2; 20, INCH-4; 21, INCH-6; 22, MJIR-2; 23, MJIR-3; 24, MJIR-4; 25, MJIR-6; 26, CICH-2; 27, CICH-3; 28, BOIR-1; dan 29, PUCH-1.

Tabel 4 Homologi nukleotida gen 16S rRNA isolat-isolat bakteri asal padi dengan B. glumae yang tersedia di Genbank dengan program BLAST

\begin{tabular}{lccc}
\hline Kode Isolat & $\begin{array}{c}\text { Homologi } \\
(\%)\end{array}$ & $\begin{array}{c}\text { No. Aksesi } \\
\text { Genbank }\end{array}$ & Asal Negara \\
\hline KRCH-1 & 94 & MF139571.1 & Korea Selatan \\
KRCH-2 & 99 & EF193639.1 & Republik Panama \\
KRCH-3 & 94 & KX158298.1 & Peru \\
KRCH-4 & 99 & EF193638.1 & Republik Panama \\
KRCH-5 & 92 & RF193638.1 & Republik Panaman \\
KRCH-6 & 99 & KF139571.1 & Korea Selatan \\
KRCH-7 & 99 & EF193638.1 & Korea Selatan \\
KRCH-8 & 99 & MF139571.1 & Korea Selatan \\
KRMK-1 & MF139571.1 & Korea Selatan \\
KRMK-3 & MK027361.1 & Peru \\
KRI32-1 & MF139571.1 & Korea Selatan \\
KRI32-2 & 90 & MK027361.1 & Peru \\
SUCH-1 & MK027361.1 & Peru \\
SUCH-4 & 99 & MK027361.1 & Peru \\
SUI30-1 & 93 & EF193638.1 & Republik Panama \\
SUI30-2 & 97 & EF193638.1 & Republik Panama \\
SUI30-5 & 91 & MF139571.1 & Korea Selatan \\
INCH-1 & 99 & MK027361.1 & Peru \\
INCH-2 & 99 & MK027361.1 & Peru \\
INCH 4 & 99 & EF193639.1 & Peru \\
INCH-6 & KX158298.1 & Republik Panama \\
MJIR-2 & 88 & EF193639.1 & Peru \\
MJIR-3 & 91 & EF193639.1 & Republik Panama \\
MJIR-4 & 95 & Republik Panama \\
MJIR-6 & 99 & EF19363638.1 & Colombia \\
CICH-2 & 90 & RF193639.1 & Republik Panama \\
CICH-3 & 99 & Republik Panama Pama \\
BOIR-1 & 99 & 95 & \\
PUCH-1 & 99 & & \\
\hline
\end{tabular}




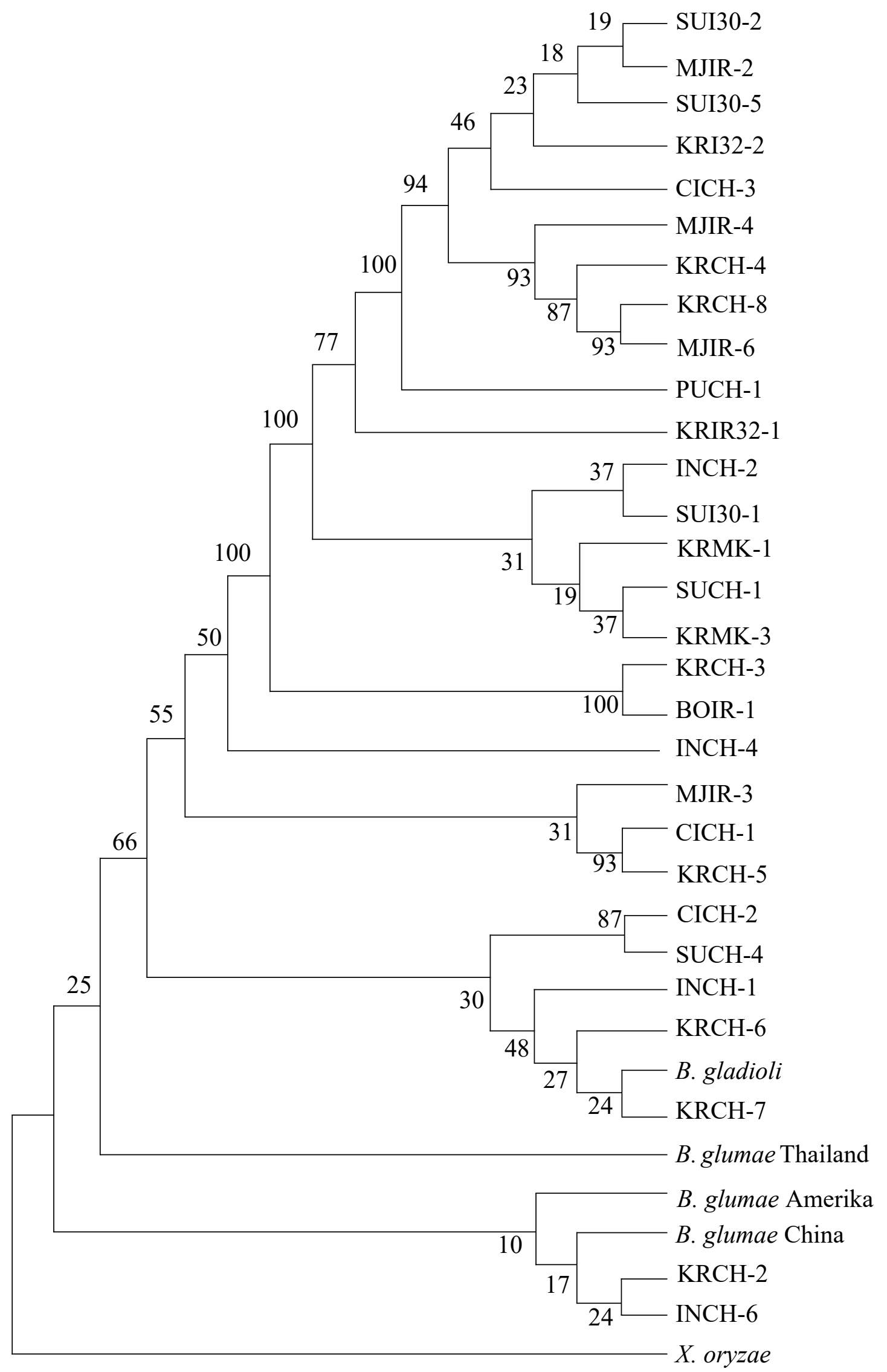

Gambar 8 Pohon filogenetika sikuen nukleotida gen 16S rRNA B. glumae dengan metode neighbour joining tree. 


\section{PEMBAHASAN}

Gejala penyakit busuk bulir padi yang ditemukan di daerah Jawa Barat sesuai dengan penjelasan Fory et al. (2014), yaitu gejala awal berupa titik atau garis cokelat pada bulir. Gejala lanjut berupa malai tegak karena biji tidak terisi penuh, ranting malai tegak berwarna hijau dengan tulang cabang berwarna hijau. Gejala khas pada bulir ditandai dengan terbentuknya garis sehingga tampak adanya gradasi warna pada lemma dan palea (discoloration)(Jeong etal. 2003). Infeksiyang parah dapat mengakibatkan pelunakan pada beras, kemandulan spikelet, dan kehampaan bulir padi sehingga mengakibatkan perubahan bobot benih.

Secara umum, keragaman varietas padi lebih tinggi pada dataran rendah. Namun demikian, tidak terdapat perbedaan insidensi penyakit pada wilayah kategori $1(0-200 \mathrm{~m} \mathrm{dpl})$ dan 2 (201-500 m dpl). Gambaran kondisi yang optimum untuk perkembangan $B$. glumae dijumpai pada wilayah dengan ketinggian 0-500 m dpl (Karawang, Indramayu, Subang, Majalengka, Cianjur, Bogor, Purwakarta) saat sedang musim hujan. Suhu maksimum di daerah ini dapat mencapai $29-34{ }^{\circ} \mathrm{C}$ dengan kelembapan udara lebih dari $80 \%$ (Accuweather 2018) sehingga mendukung infeksi $B$. glumae. Daerah dengan ketinggian $>500 \mathrm{~m}$ dpl cenderung memiliki suhu rendah sehingga kurang mendukung keberhasilan infeksi bakteri.

Gejala busuk bakteri tidak ditemukan pada beberapa varietas, termasuk var. Ciherang yang sebelumnya menunjukkan respons sangat rentan pada percobaan uji ketahanan varietas padi terhadap penyakit hawar malai oleh B. glumae (Safni dan Lubis et al. 2009). Gejala tidak ditemukan karena berhubungan dengan beberapa faktor yang diperlukan untuk terjadinya suatu infeksi. Lee et al. (2004) menyatakan bahwa terdapat 3 faktor yang memengaruhi kemampuan dan keberhasilan infeksi bakteri, yaitu suhu, kelembapan dan fase pertumbuhan tanaman. Fase pertumbuhan tanaman yang paling menentukan keberhasilan infeksi adalah heading time $(40 \%$ muncul malai). Insidensi penyakit berkorelasi tinggi dengan suhu harian selama 7 dan 10 hari dengan kelembapan relatif minimum selama 15 hari dari 3 hari sebelum dan 3 hari setelah heading time. Suhu dan kelembapan tinggi pada fase berbunga merupakan kondisi kondusif untuk infeksi bakteri (Tsushima 1996). B. glumae dapat hidup pada suhu $20-41{ }^{\circ} \mathrm{C}$, dengan kondisi optimum pada $30-31{ }^{\circ} \mathrm{C}$, dan cocok pada kondisi malam hangat dengan frekuensi hujan yang tinggi (Nandakumar 2009; Cui et al. 2016). Toksoflavin sebagai salah satu faktor virulensi hanya diproduksi pada suhu 25-37 ${ }^{\circ} \mathrm{C}$.

Berdasarkan warna koloni di medium S-PG, ditemukan koloni bakteri tipe A dan B. Koloni tipe A ditemukan hampir pada semua lokasi, sedangkan koloni tipe B cenderung mendominasi pada dataran rendah. Perbedaan warna koloni ini dapat disebabkan oleh faktor fenotip serta tingkat produksi toksoflavin masing-masing isolat. Tidak semua isolat bakteri hasil isolasi menghasilkan toksoflavin. Isolat yang tidak menghasilkan toksoflavin, mampu menghasilkan gejala dengan skor 1, sementara isolat yang menghasilkan toksoflavin mampu menimbulkan gejala hingga skor tertinggi. Namun isolat yang tidak menghasilkan pigmen pun dapat bersifat virulen (Karki 2010). Sebaliknya, isolat yang menghasilkan pigmen ada yang bersifat avirulen. Semua isolat yang tidak menghasilkan toksoflavin (KRI32-1, PUCH-1, MJIR-2, MJIR-4) merupakan tipe koloni B dan memiliki hubungan kekerabatan yang dekat secara genetik. Bakteri B. gladioli yang masih tergolong OPTK A1 mempunyai hubungan kekerabatan yang dekat dengan isolat CICH2, SUCH-4, INCH-1, KRCH-6, dan KRCH-7. Isolat B. glumae asal Cina dan Amerika memiliki kedekatan dengan isolat $\mathrm{KRCH}-2$ (Karawang) dan INCH-6 (Indramayu).

Bakteri B. glumae merupakan bakteri terbawa benih sehingga dapat terinfestasi pada bulir tetapi tidak menghasilkan gejala. Biji yang tidak bergejala dapat positif terinfestasi B. glumae (Bo et al. 2008). Sifat terbawa benih ini diduga merupakan salah satu penyebab bakteri menyebar ke wilayah di Indonesia, 
termasuk di Jawa Barat. Berdasarkan status daerah sebarnya, B. glumae yang semula berstatus sebagai organisme pengganggu tumbuhan karantina (OPTK) kategori A2 melalui permentan nomor 51 Tahun 2015 (Kementan 2015), saat ini telah berubah status menjadi organisme pengganggu tumbuhan (OPT) berdasarkan permentan Nomor 31/ kementan/KR.010/7/2018. Berdasarkan hasil uji biokimia, fisiologi, dan molekuler, isolat yang terkonfirmasi sebagai B. glumae berjumlah 29 isolat dengan variasi fenotip dan genotip.

\section{UCAPAN TERIMA KASIH}

Ucapan terima kasih disampaikan kepada Kementerian Pertanian Republik Indonesia yang telah mendanai penelitian ini melalui program Tugas Belajar Program Master (S2) di Dalam Negeri Tahun 2016 dan Balai Besar Peramalan Organisme Pengganggu Tumbuhan atas fasilitas penelitian yang diberikan.

\section{DAFTAR PUSTAKA}

Accuweather. 2018. Indonesia cuaca. Tersedia pada https://www.accuweather.com. diunduh pada 17 Juli 2019.

Baharuddin, Harniati R, Faisal F. Yani A. Suparni, Hamid H, Kuswinanti T, Jahuddin R. 2017. Keberadaan penyakit busuk bulir (Burkolderia glumae) pada tanaman padi di Sulawesi Selatan. Prosiding Simposium Nasional Fitopatologi. Bogor (ID): Institut Pertanian Bogor. Hlm 19-16.

Bo Z, Lou MM, Huai Y, Xie GL, Luo JY, Xu LH. 2008. Isolation and identification of Burkholderia glumae from syptomless rice seeds. Chin J Rice Sci. 22(1):82-86.

Chun W, Jones JB. 2001. Gram negative bacteria: Burkholderia. Di dalam Schaad, NW, Jones JB, Chun W, editor. Laboratory Guide for Identification of Plant Pathogenic Bacteria. $3^{\text {rd }}$ edition. New York (US): APS Press. Hlm $1-6$.

Cui ZQ, Zhu B, Xie GL, Li B, Huang SW. 2016. Research status and prospect of Burkholderia glumae, the pathogen causing bacterial panicle blight. Rice Science. 23(3):111-118. DOI: https://doi. org/10.1016/j.rsci.2016.01.007.

[DBPTP] Direktorat Bina Perlindungan Tanaman Pangan. 1992. Penyakit padi. Laporan Akhir. Jakarta (ID): Direktrorat Jenderal Tanaman Pangan Kementerian Pertanian.

[DPTP] Direktorat Perlindungan Tanaman Pangan. 2018. Petunjuk teknis pengamatan dan pelaporan organisme pengganggu tumbuhan dan dampak perubahan iklim (OPT-DPI). Jakarta (ID): Kementerian Pertanian. Hlm 17.

Fory PA, Triplett L, Ballen C, Abello JF, Duitama J, Aricapa MG, Prado GA, Correa F, Hamilton J, Leach JE, Tohme J, Mosquera GM. 2014. Comparative analysis of two emerging rice seed bacterial pathogens. Phytopathology. 104(5):436-444. DOI: https://doi.org/10.1094/PHYTO-07-130186-R.

Handiyanti M, Subandiyah S. Joko T. 2018. Deteksi molekuler Burkholderia glumae, penyebab penyakit hawar malai padi. JPTI. 22(1):98-107. DOI: https://doi. org/10.22146/jpti.30259.

Jeong Y, Kim J, Suhyun K, Yongsung K. 2003. Toxoflavin produced by Burkholderia glumae causing rice grain rot is responsible for inducing bacterial wilt in many field crops. Plant disease. 87(8):890894. DOI: https://doi.org/10.1094/ PDIS.2003.87.8.890.

Joko T. 2017. Burkholderia glumae sebagai emerging pathogen: status, potensi kerusakan, dan strategi pengendalian. Prosiding Simposium Nasional Fitopatologi. Bogor (ID): Institut Pertanian Bogor. Hlm 27-35.

Karki HS. 2010. Physiological, biochemical, and molecular characteristic associated with virulence of Burkholderia glumae: the major causative agent of bacterial panicle blight of rice. [Thesis]. Nepal (IN): Institute of Agriculture and Animal Science, Rampur, TU.

Karki HS, Shrestha B, Han JW, Groth De, Barphagha IK, Rush MC, Melanson RA, 
Kim BS, Ham JH. 2012. Diversities in virulence, antifungalactivity, pigmentation, virulence, and DNA fingerprint among strain of Burkholderia glumae. Plus One. 7(9):1-12. DOI: https://doi.org/10.1371/ journal.pone.0045376.

[Kementan] Kementerian Pertanian. 2015. Peraturan Menteri Pertanian No 51/ Permentan/KR.010/9/2015 tentang Jenis Organisme Pengganggu Tumbuhan Karantina. Jakarta (ID): Kementan.

[Kementan] Kementerian Pertanian. 2018. Peraturan Menteri Pertanian No 31/ Permentan/KR.010/7/2018 tentang perubahan kedua atas peraturan meneteri pertanian nomor 93/permentan/ OT.140./12/2011 tentang Jenis Organisme Pengganggu Tumbuhan Karantina. Jakarta (ID): Kementan.

Lim JY, Lee TH, Nahm BH, Choi YD. Kim M, Hwang I. 2009. Genome announcement. Complete genome sequence of Burkholderia glumae BGR1. J Bacteriol. 191(11):3758-3759. DOI: https://doi. org/10.1128/JB.00349-09.

Lu W, Pan L, Zao H, Jia Y, Wang Y, Yu X, Wang X. 2014. Molecular detection of Xanthomonas oryzae pv. oryzae, Xanthomonas oryzae pv. oryzicola, and Burkholderia glumae in infected rice seeds and leaves. The Crop Journal. 2:398-406. DOI: https://doi.org/10.1016/j. cj.2014.06.005.
Nandakumar R, Shahjana AKM, Yuan XL, Dickstein ER, Groth DE, Clark CA, Cartwright RD, Rush MC. 2009. Burkholderia glumae and B. gladioli cause bacterial panicle blight in rice in the southern united states. Plant Dis. 93(9):896-905. DOI: https://doi. org/10.1094/PDIS-93-9-0896.

Pradhaph M, Selvisabhanayakam, Mathvianan V, Ayyapan JVAA, Kumar SS. 2011. Study on 16S rRNA based PCR Method for specific detection on Salmonella entrica typhi from gut of infected silkworm bomyx mori . JSIR. 70(11):909-911.

Tsushima S. 1996. Epidemiology of bacterial grain rot of rice caused by Pseudomonas glumae. JARQ. 30:85-89.

Safni I, Lubis K. 2019. Screening for disease resistance in rice varieties against bacterial panicle blight disease (Burkholderia glumae) in Northern Sumatra of Indonesia. IOP Conference Series: Earth and Environmental Science. 260(1):012118. DOI: https://doi.org/10.1088/17551315/260/1/012118.

Wiyono S, Mutaqin KH, Hidayat SH, Supramana, Widodo, 2017. Emerging disease pada tanaman pertanian: strategi dan opsi kebijakan pengendalian. Prosiding Simposium Nasional Fitopatologi. Bogor (ID): Institut Pertanian Bogor. Hlm 1-11. 